УДК 346.91(477)

DOI https://doi.org/10.32849/2663-5313/2019.12.23

\title{
Юрій Ужакін,
}

аспірант Науково-дослідного інституту приватного права і підприємництва

імені академіка Ф. Г. Бурчака

Національної академії правових наук України

\section{ПІДСТАВИ СУДОВОГО РОЗСУДУ ПРИ ВСТАНОВЛЕННІ ФАКТУ ЗЛОВЖИВАННЯ ПРОЦЕСУАЛЬНИМИ ПРАВАМИ У ГОСПОДАРСЬКОМУ ПРОЦЕСІ}

Ця стаття присвячена аналізу правових засобів уповноваження господарського суду на здійснення судового розсуду. Це дослідження базується на нормах Господарського процесуального кодексу України, присвячених регулюванню зловживання процесуальними правами.

Зловживання процесуальними правами є процесуальним правопорушенням. Таке правопорушення може бути скоєне будь-якими учасниками господарського процесу. Кодекс містить групу спечіальних приписів, які визначають ознаки факту зловживання процесуальними правами та встановлюють санкиї за ие правопорушення. Особливість цих норм полягає в тому, що їх застосування вимагає здійснення судової дискреції. Юридична доктрина визначає судовий розсуд як повноваження суду здійснити вибір між декількома правовими можливостями. Основна причина для надання суду повноваження робити такий вибір полягає в існуванні великого різноманіття вчинків, що становлять зловживання проиесуальними правами. Законодавець не може встановити ознаки усіх видів зловживання. Недобросовісні учасники господарського прочесу винаходять нові способи зашкодити суду досягти вирішення завдань господарського судочинства. Все різноманіття способів зловживання не може бути втілене у конкретній нормі чи законі. Відповідно до иього існує потреба у вповноваженні правозастосовия на здійснення розсуду.

Юридича наука описує різні підходи до питання джерел повноваження на здійснення судового розсуду. Більшість авторів згадує оиіночні категорії, такі як добросовісність, розумність, справедливість. Також згадується проста вказівка на здійснення розсуду.

Автор дійшов висновку, шо сучасне господарське проиесуальне право Украӥни наділяє суд відповідними повноваженнями шляхом використання оціночних понять, наприклад, добросовісності, розумності. Крім того, у чинному ГПК використання оиіночних понять поєднується із простою вказівкою на застосування судового розсуду. Таке поєднання дозволяє досягти справедливих та розумних результатів. Відповідно до иього у чинному ГПК встановлене застосування комбінації обох зазначених засобів встановлення зловживання прочесуальними правами.

Ключові слова: зловживання процесуальними правами, судовий розсуд, підстави здійснення судового розсуду, оціночні категорії, пряма вказівка на здійснення судового розсуду, комбінація засобів вповноваження на здійснення розсуду.

Постановка проблеми. Чинний Господарський процесуальний кодекс України (далі - ГПК, Кодекс) не містить терміна «судовий розсуд» чи аналогічних за змістом термінів. Проте застосування багатьох норм матеріального та процесуального права потребує здійснення судом владного вибору належного варіанту поведінки із кола дозволених законом, що отримало у доктрині процесуального права назву судового розсуду (дискреції)

Професор А. Барак вдало підкреслив значущість вірного розуміння судового розсуду: «Суддя повинен здійснювати свій розсуд як розумний суддя. Щоб так діяти, він повинен усвідомлювати той факт, що у нього є право розсуду, усвідомлювати значення розсуду та різні фактори, які потрібно зважити в контексті цього розсуду» [1, с. 152]. До цього можна додати, що не лише суддя, а й інші учасники судового процесу повинні мати на увазі фактор правозастосування із використанням судової дискреції, межі судового розсуду, фактори, що впливають на напрями вибору належного варіанту поведінки.

Отже, одним із важливих завдань правової доктрини слід визнати дослідження правових засобів встановлення повноваження на прийняття рішення із використанням судового розсуду. 
За відсутності спеціальних норм щодо судового розсуду питання, що пов'язані iз його застосуванням, мають вивчатися шляхом аналізу норм, застосування яких пов'язане із розсудом суду. Одним із інститутів процесуального права, який тісно пов'язаний із уповноваженням суду на здійснення розсуду, є інститут заборони зловживання процесуальними правами.

Метою статті $є$ аналіз правових засобів встановлення у процесуальному законодавстві повноваження господарського суду на здійснення судового розсуду. Аналіз здійснюватиметься на прикладі встановленої процесуальним законодавством конструкції юридичного факту (фактичного складу) зловживання процесуальними правами. Дослідження дозволить виявити механізми наділення господарського суду повноваженням на здійснення судового розсуду при встановленні факту зловживання процесуальними правами, зробити певні загальні висновки щодо механізмів наділення господарського суду повноваженням на прийняття процесуальних ॥ рішень із використанням судового розсуду.

Проблему судового розсуду було досліджено доктриною англосаксонської правової сім'ї. Серед дослідників слід згадати класиків процесуальної доктрини, таких як О. Холмс, Б. Кардозо. Серед більш сучасних науковців виділяються дослідження Г. Харта, Р. Дворкіна, А. Барака. Серед науковців, праці яких створено переважно на матеріалі континентального права, необхідно згадати, зокрема, представників школи живого права, таких як Є. Ерліх, Я. Канторович та ін., якими було досліджене питання свободи у правозастосовній діяльності суду.

Серед дослідників Російської імперії, колишнього СРСР, РФ та України внески, що мають значення для дослідження проблем судового розсуду, зроблено такими вченими, як Д.Б. Абушенко, Л.Н. Берг, О.Т. Боннер, Е.В. Васьковський, С.Ф. Демченко, К.Т. Коміссаров, П.В. Куфтирев, О.А. Папкова, Д.М. Притика, Т.А. Покровський, Н.О. Чечіна, Д.М. Чечот, С.Я. Фурса.

Виклад основного матеріалу. Судовий розсуд є однією із важливих складових частин правозастосовної діяльності господарського суду. Це стосується застосування як норм матеріального, так і процесуального права.

У багатьох випадках надмірно детальне регулювання законодавством господарських відносин $€$ недоцільним та неможливим. Вирішення відповідних суперечливих питань відбувається шляхом делегування господар- ському суду повноваження на вирішення спору із врахуванням конкретних обставин через здійснення судом владного вибору належного варіанта поведінки, конкретизації загальних приписів права. У вітчизняній правовій літературі даний феномен отримав назву судового розсуду.

Визначаючи сутність судового розсуду, представники доктрини наголошували на різних аспектах цього явища. Серед наведених у науковій літературі позицій слід згадати розуміння судового розсуду як свободи, повноваження, права вибору із декількох альтернатив, різновиду правозастосовної діяльності тощо. Різноманітність висловлених точок зору зумовлена різними підходами до дослідження судової дискреції. При цьому висловлені думки не завжди суперечать одна іншій, підкреслюючи різні сторони досліджуваного явища.

Розуміння судового розсуду як повноваження має істотну підтримку у науковій літературі. Автор однієї із класичних робіт, що досліджує питання судової дискреції, Аарон Барак так визначав загальне поняття розсуду: «Для мене розсуд - це повноваження, дане особі, яка має владу вибирати між двома або більше альтернативами, коли кожна з альтернатив законна» [1, с. 13].

Як і будь-яке інше повноваження, право на здійснення судом владного вибору із декількох альтернатив повинно грунтуватися на приписах правових норм та не може презумуватися. Це випливає, зокрема, із положень ч. 2 ст. 19 Конституції України, згідно з якими органи державної влади та органи місцевого самоврядування, їх посадові особи зобов'язані діяти лише на підставі, в межах повноважень та у спосіб, що передбачені Конституцією та законами України.

Сучасна правова наука (як загальна теорія права, так і наука галузева) керується наявністю в законодавстві різних способів наділення суду правом прийняття рішення з використанням судового розсуду. Наприклад, I.В. Булгакова, яка досліджувала питання судового розсуду у господарському процесі, звернула увагу на три способи, за допомогою яких законодавець встановлює право вибору для правозастосовувача. Це звичайна вказівка на судовий розсуд, оціночні категорії, комбінований спосіб [2, с. 47, 48].

При дослідженні питання підстав судового розсуду необхідно мати на увазі, що не всі автори здійснюють чітке термінологічне виділення саме правових підстав дискреції. Часто мова йде про джерела судового розсуду, види судового розсуду. Врахування поглядів цих дослідників $є$ необхідним, оскільки в основу класифікації судової дис- 
креції на види доволі часто кладуться саме механізми наділення суду відповідними повноваженнями

Наприклад, М.Б. Гарієвська відзначає такі способи встановлення судового розсуду (у термінології автора - види дискреційних повноважень за способами нормативної визначеності): дискреційні повноваження, що виникають із прямої вказівки закону; дискреційні повноваження суду, які виникають на основі застосування оціночних понять; дискреційні повноваження суду, що виникають на основі відносно визначених норм; дискреційні повноваження, що виражаються у формі ініціативи суду [3, с. 170-173].

Ю.В. Білоусов, М.Б. Рибчак, досліджуючи, зокрема, мотиви, які мають значення для судової дискреції, згадують як джерела відповідного повноваження просту вказівку у нормі та використання оціночних категорій. [4, с. 104].

Д.Б. Абушенко наводить 3 способи встановлення свободи правозастосування - просту вказівку, використання оціночних категорій, комбінований спосіб [5, с. 52]. О.А. Папкова відзначає існування відносно визначеного судового розсуду та правомочного розсуду. Перший вид поділяється цією авторкою на ситуаційний судовий розсуд та альтернативний [6, с. 332].

Вчені зарубіжних країн також висловлюють різні думки щодо досліджуваного питання. Наприклад, професор Г. Харт вказує на використання термінів з відкритою структурою (open texture) [7, с. 131]. Професор А. Барак розрізняє матеріальні та формальні джерела судового розсуду. Матеріальними джерелами розсуду при застосуванні законодавчої норми він вважає невизначеність мови правила, невизначеність нормативної схеми, невизначеність в правилах тлумачення, невизначеність щодо обставин застосування правила тлумачення, невизначеність щодо змісту правила тлумачення тощо [1, с. 63-96]. На свідомому застосуванні нечітких понять наголошує проф. George Christie [8, c. 889].

Як зазначалося вище, у чинному матеріальному та процесуальному законодавстві відсутні приписи, що безпосередньо регулюють судовий розсуд. Це зумовлює необхідність досліджувати дискрецію на прикладі норм права, які регулюють інші правові явища, але застосування яких пов'язане із судовим розсудом.

Серед норм процесуального права, застосування яких пов'язане із судовим розсудом, звертають на себе увагу приписи щодо заборони зловживання процесуальними правами. Тісний зв'язок приписів щодо зло- вживання процесуальними правами із судовою дискрецією втілюється, крім іншого, у поєднанні в рамках цього інституту різних механізмів наділення суду повноваженням на здійснення розсуду.

Вчинення учасником судового процесу зловживання процесуальними правами є підставою застосування низки правових наслідків. Зокрема, суд має право залишити без розгляду або повернути скаргу, заяву, клопотання (ч. 3 ст. 43 ГПК), вжити заходів забезпечення судових витрат (ч. 4 ст. 125 ГПК), покласти судові витрати на особу, яка зловживала правом (ч. 9 ст. 129 ГПК), вжити заходів процесуального примусу (ст. 131, 135 ГПК), винести окрему ухвалу (ст. 246 ГПК). Підставою настання відповідних правових наслідків є зловживання процесуальними правами, що дозволяє розглядати зловживання як юридичний факт.

У науковій літературі висловлені різні думки щодо поняття «зловживання правами», зокрема й процесуальними. На думку більшості науковців, зловживанню правом притаманна недобросовісна реалізація суб'єктивного права не за його призначенням, заподіяння шкоди суспільним інтересам та правам третіх осіб.

Легальне визначення ознак відповідного правопорушення може бути виведене із тлумачення приписів частин 1 та 2 ст. 43 ГПК, положення яких становлять певну єдність та мають тлумачитися із врахуванням цієї смислової єдності. Попри певну нечіткість, процесуальний закон в цій частині загалом побудований із врахуванням теоретичних поглядів на зловживання як на недобросовісні дії суб'єкта права, що вчинене під час реалізації суб'єктивних прав та у протиріччі із призначенням відповідного суб'єктивного права.

Частина 1 ст. 43 Кодексу встановлюе вимогу добросовісного використання процесуальних прав. Далі процесуальний закон містить таке положення: «<..> зловживання процесуальними правами не допускається». Відповідно до ч. 2 ст. 43 ГПК передбачено, зокрема, таке: «Залежно від конкретних обставин суд може визнати зловживанням процесуальними правами дії, що суперечать завданню господарського судочинства, зокрема <...>. Далі ч. 2 ст. 43 ГПК містить перелік окремих видів зловживання правом.

Використання слова «зокрема» у конструкції норми ч. 2 ст. 43 Кодексу дає підстави вважати, що перелічені після цього слова різновиди зловживання (подання завідомо безпідставного позову, позову за відсутності предмета спору тощо) не вичерпують обсяг поняття зловживання проце- 
суальними правами, а перелік конкретних форм вчинення зловживання процесуальними правами є відкритим.

На думку автора, процесуальний закон побудований на поєднанні загального типу правопорушення - зловживання процесуальними правами - із окремими, більш конкретизованими його видами. Загальна конструкція складу процесуального правопорушення - зловживання процесуальними правами - має двояке правове значення, $€$ як самостійною підставою для визнання дій учасника процесу у якості зловживання правом, так і нормативним узагальненням, що дає орієнтири для тлумачення окремих видів зловживання, що перелічені у пунктах 1-5 ч. 2 ст. 43 Кодексу. Наприклад, помилкове подання декількох позовів до одного відповідача $з$ одним предметом та 3 одних підстав, якщо відсутні ознаки навмисної недобросовісної поведінки позивача, інші суттєві ознаки зловживання правом, не може розглядатися як зловживання процесуальними правами. У такому разі $€$ підстави для повернення позовної заяви на підставі п. 5 ч. 5 ст. 174 ГПК, а не застосування ст. 43 Кодексу, вжиття інших заходів, зокрема й накладання штрафу.

Ознаки факту відповідного правопорушення, що використані законодавцем у ст. 43 ГПК, сконструйовані із використанням певної сукупності правових засобів, які тісно пов'язані із судовою дискрецією, є її правовою підставою. Звертає на себе увагу наявність у ст. 43 Кодексу оціночних понять.

Одним із перших вітчизняних науковців, який досліджував питання оціночних понять, був проф. С.І. Вільнянський, який зазначав, що оціночні поняття надають суду можливість вільної оцінки фактів і врахування індивідуальних особливостей конкретного випадку за обов'язкового застосування закону [9, с. 14].

Сучасний дослідник Р.О. Опалєв відзначає: «Під оціночними розуміються загальні, абстрактні, нечіткі поняття, які виражені в джерелах права, що регулюють порядок цивільного та адміністративного судочинства, і призначені для надання правозастосовцю в рамках конкретної справи відносної свободи дій» [10, с. 33].

Оціночні поняття містяться в описі загального типу правопорушення та його окремих різновидах. Стаття 43 Кодексу містить, зокрема, такі вирази: «добросовісно користуватися процесуальними правами», «суперечать завданню господарського судочинства», «заявлення завідомо безпідставного відводу або вчинення інших аналогічних дій», «подання декількох позовів
3 аналогічним предметом і 3 аналогічних підстав або вчинення інших дій, метою яких <..>», «подання завідомо безпідставного позову, <...> або у спорі, який має очевидно штучний характер», «необгрунтоване або штучне об'єднання позовних вимог» тощо. Аналогічність предмета та підстав, аналогічність дій, штучність об'єднання, завідомість, суперечність завданню господарського судочинства тощо можуть бути встановлені в результаті оцінки судом характеру та цілей конкретних процесуальних дій учасників судового процесу, інших обставин справи, їх зіставлення із керівними ідеями судочинства.

Особливу роль в кваліфікації поведінки як зловживання процесуальними правами відіграють пов'язані між собою принципи добросовісності, справедливості, розумності. Хоча останні два принципи не згадуються безпосередньо в аналізованій нормі, саме ці ідеї у своїй сукупності та взаємному зв'язку встановлюють основні вимоги до реалізації прав та виконання обов'язків.

Професор О.О. Бакалінська зазначає: «За всієї множинності різновидів оціночних понять у цивільному праві ми вважаємо, що найпоширенішими оціночними поняттями українського цивільного права та процесу $€$ такі: добросовісність, розумність, справедливість (тобто встановлення рівних умов для участі всіх осіб), закріплення можливості адекватного захисту порушеного цивільного права або інтересу, забезпечення реалізації цивільного права з шануванням прав та інтересів інших осіб» $[11$, с. 8].

Використання оціночних понять не вичерпує арсенал правових засобів встановлення повноваження на здійснення судового розсуду. Частина 2 ст. 43 ГПК починається такими словами: «Залежно від конкретних обставин суд може визнати <..>».

Як вбачається із наведеної цитати, процесуальний закон містить вповноважуючу конструкцію «може визнати». Це право визнати дії зловживанням процесуальними правами поставлене текстом Кодексу у залежність від конкретних обставин, перелік яких у законі відсутній.

На думку автора, це положення закону має важливе самостійне значення в конструкції юридичного факту зловживання процесуальними правами. Мета даного положення полягає в певному обмеженні загального складу зловживання процесуальними правами. Такий висновок випливає 3 обмежувального сенсу наведеного формулювання. Без врахування цього положення ч. 2 ст. 43 передбачала б визнання зловживанням дій, які суперечать завданням судочинства. 
Завдання господарського судочинства сформульовані процесуальним законодавством (ст. 2 ГПК) досить широко. Головним завданням господарського судочинства $€$ ефективний та оперативний захист порушених або оспорюваних прав та інтересів. 3 цієї точки зору будь-яке необгрунтоване клопотання, заперечення факту, який виявися таким, що існує, ускладнює процес та певною мірою суперечить завданню господарського судочинства, тобто необхідності справедливого, неупередженого та своєчасного вирішення спорів, ефективного захисту порушених, невизнаних або оскаржуваних прав і законних інтересів. Визнання зловживанням будь-яких дій, що не відповідають завданню судочинства, веде до охоплення цим поняттям будь-яких дій, що ускладнюють процес. Таке надмірно широке розуміння зловживання процесуальними правами здатне призвести до девальвації одного з основоположних принципів процесу - змагальності. Радикальне розширення поняття «зловживання процесуальними правами», особливо у поєднанні із застосуванням істотних заходів відповідальності (наприклад, накладенням штрафу, винесенням окремої ухвали), спроможне підірвати основи змагальності судочинства.

Заборона зловживання процесуальними правами не повинна призводити до виникнення своєрідного обов'язку визнання законних вимог іншої сторони чи заборони пред'явлення вимог, які у майбутньому не будуть задоволені судом. Не треба забувати, що значна кількість вимог та заперечень має досить суперечливий і неочевидний характер, в тому числі і для самих учасників матеріальних правовідносин. Не може каратися лише спроба захистити спірні вимоги та заперечення.

Зрештою, існує необхідність тонкого балансу між свободою реалізації учасниками своїх прав, змагальністю господарського процесу та необхідністю припинення недобросовісної поведінки. Саме судова дискреція покликана відігравати провідну роль у розрізненні нормальної змагальності процесу та недобросовісних випадків зловживання правом.

Отже, обмежуюча конструкція «залежно від конкретних обставин суд може визнати зловживанням <..>» дає підстави вважати, що протиріччя дій учасника процесу завданню господарського судочинства $\epsilon$ необхідною, але недостатньою умовою для визнання поведінки зловживанням правом.

Категорія «конкретні обставини», наведена у ГПК, не може вважатися оціночним терміном у точному розумінні. Також ГПК не містить вказівок на те, які саме конкретні обставини справи повинен врахувати суд. Закон містить лише вказівку на категорію «конкретні обставини справи» у поєднанні із вповноважуючою конструкцією «може визнати».

Цю форму наділення суду повноваженням здійснювати дискрецію слід вважати простою вказівкою. Які обставини будуть визнані судом істотними і юридично значущими для цілей застосування ст. 43 ГПК визначає суд на свій розсуд. Саме судовий розсуд покликаний надати юридичне значення тим чи іншим фактам.

Уявляється, що суд, здійснюючи свій вибір у питанні наділення юридичним значенням тих чи інших обставин, повинен врахувати, зокрема, дії відповідного учасника судового процесу, поведінку інших учасників, систематичність спроб перешкоджання вирішенню спору, наслідки таких дій, їх мету та інші обставинні. Факти, яким суд надає юридичне значення, повинні характеризувати поведінку учасника процесу як свідому, цілеспрямовану, недобросовісну, таку, що суперечить загальноприйнятим стандартам чесного здійснення процесуальних прав.

Через посилання на врахування конкретних обставин справи процесуальний закон уповноважує суд здійснити оцінку дій учасників через призму балансу загальноправових принципів, принципів процесуального права, змагальної моделі процесу, основоположних етичних норм.

Зазначена вказівка на дискрецію перебуває у системному зв'язку із дискреційними повноваженнями, що випливають із оціночних категорій, зокрема, вводячи обмежувальні критерії. Таким чином, стаття 43 ГПК встановлює своєрідну кумулятивну дискрецію суду.

Цей системний зв'язок оціночних категорій та простої вказівки при встановленні повноваження здійснювати судовий розсуд для цілей встановлення факту зловживання правом приводить до висновку, що законодавцем використаний комбінований спосіб, який поєднує оціночні поняття та просту вказівку на судовий розсуд. Відповідні положення складають зміст гіпотези відносно визначених норм, що визначають наслідки зловживання процесуальними правами.

\section{Висновки}

Підсумовуючи викладене, ми дійшли таких висновків. Вчинення зловживання процесуальними правами слід вважати юридичним фактом. Особливості законодавчої конструкції складу цього факту полягають в тому, що ознаки цього факту встановлені відносно визначеними гіпотезами процесуального закону із використанням оціночних 
категорій, що поєднуються із простою вказівкою на дискреційне повноваження суду. Обрана законодавцем конструкція юридичного факту має своїм наслідком те, що оцінка фактичних обставин справи стосовно їх кваліфікації як зловживання здійснюється із використанням судом дискреційного повноваження. Зазначене поєднання різних способів вповноваження господарського суду здійснити дискрецію випливає із необхідності врахування різних факторів. ІІх зв'язок має системний характер та повинен розглядатися як комбінований спосіб наділення суду відповідним повноваженням.

\section{Список використаних джерел:}

1. Барак А. Судейское усмотрение / пер. с англ. Москва : НОРМА, 1999. 376 с.

2. Булгакова I.В. Судовий розсуд у господарському процесі. Вісник Академії адвокатури Украйни. 2005. Вип. 3. С. 44-49. URL: http:// nbuv.gov.ua/UJRN/vaau 200538 .

3. Гарієвська М.Б. Питання класифікації дискреційних повноважень суду першої інстанції у цивільному судочинстві. Університетські наукові записки. 2012. № 4. С. 169-175. URL: http://nbuv.gov.ua/UJRN/Unzap_2012_4_26.

4. Білоусов Ю.В., Рибчак М.Б. Поняття та ознаки дискреційних повноважень суду у цивіль- ному процесі. Університетські наукові записки. 2007. № 4. C. 100-108. URL: http://nbuv.gov.ua/ UJRN/Unzap_2007_4_16.

5. Абушенко Д̆.Б. Судебное усмотрение в гражданском и арбитражном процессе. Москва : Норма, 2002. $176 \mathrm{c}$.

6. Папкова О.А. Усмотрение суда. Москва : Статут, 2005. $413 \mathrm{c}$.

7. Харт Г. Понятие права. Санкт-Петербург : Из-во С.-Петербургского университета, 2007. $302 \mathrm{c}$

8. George C. Christie. Vagueness and Legal Language, 48 Minnesota Law Review 889 (1964). URL: $\quad$ https://scholarship.law.duke.edu/cgi/ viewcontent.cgi? article $=1207 \&$ context $=$ faculty_ scholarship.

9. Вильнянский С.И. Применение норм советского права. Уи. записки Харьковского юридического ин-та. Вып. 7. Харьков, 1956. 172 с.

10. Опалев Р.О. Оценочные понятия в арбитражном и гражданском процессуальном праве. Москва : Волтерс Клувер, 2008. 248 с.

11. Бакалінська O.О. Застосування оціночних понять у цивільному праві України. Підприємниитво, господарство і право : науково-практичний, господарсько-правовий журнал; Наук.-дослід. ін-т приватного права і підприємництва НАПрН України ; ТОВ «Гарантія». Київ, 2012. № 10 (202). C. 8-11. URL: http://pgp-journal.kiev.ua/ archive/2012/10_2012.pdf.

This article is devoted to the analysis of legal means of empowering the commercial court to use judicial discretion. This research is based on the rules of the Commercial and Procedural Code of Ukraine relating to abuse of process.

Abuse of process is a violation of procedural law. Such a violation can be committed by any subject of commercial procedure. The Code has a group of special legal rules which describe the fact of abuse of process (corpus delicti) and lay down sanctions for this wrong. The peculiarity of these rules is that the application of these rules calls for judicial discretion. The legal doctrine defines judicial discretion as the court's power to make choice between several legal options. The compelling reason to empower the commercial court to make choice is that there are a lot of types of acts which can be named as abuse of process. The legislature cannot describe all possible types of abusive acts. Unfair participants of the court proceedings invent new means to prevent the courts from achieving the goals of commercial procedure. The whole variety of possible unfair acts cannot be described in a single norm or legal act. Accordingly, there exists a need for the discretion of a law enforcer.

The legal science defines different approaches to the subject of the sources of judicial discretion. Most of the authors mention evaluative concepts, such as good faith, reasonableness, equity. It is also mentioned a simple instruction to use discretion.

The author concludes that the modern procedural law of Ukraine authorizes the commercial court to make choice by means of evaluative concepts, for example, good faith, reasonableness, etc. In addition, the Commercial and Procedural Code of Ukraine establishes a further rule for granting the court the power to use judicial discretion which can be described as a simple instruction. The abovementioned two legal means are interconnected with each other. Such a combination lets achieve just and reasonable results. According to this, there is a combination of the different means of the establishment of abuse of process in the Commercial and Procedural Code of Ukraine.

Key words: abuse of process, judicial discretion, sources of judicial discretion, evaluative concepts, simple instruction to use discretion, combination of the sources of judicial discretion. 